\title{
Obtention and characterization of coconut babassu derivatives
}

\author{
Roseli Aparecida Ferrari ${ }^{\star}$, Marcia Paisano Soler
}

Institute of Food Technology, Av. Brasil, 2880 - 13070-178

- Campinas, SP - Brazil.

${ }^{*}$ Corresponding author <roseliferrari@ital.sp.gov.br>

Edited by: Luís Guilherme de Lima Ferreira Guido

\begin{abstract}
Babassu (Orbignya sp.) is a palm with extraordinary socioeconomic and ecologic importance found in humid tropical areas in Brazil, especially in frequently burned and degraded landscapes. There are several uses for babassu oil; however, its potential for providing other industrial products remains unexploited, due to the lack of scale and production structure. Oil and presscake extracted from kernels are industrially produced, while the remaining parts of the babassu coconut have the potential to add value as byproducts. This study aimed to establish conditions for the preparation of the raw material fruit of babassu for oil extraction by pressing and producing biodiesel by ethanolic transesterification. Babassu coconuts were dried at 75 and $90^{\circ} \mathrm{C}$. The separation of the fractions rich in fiber, starch, kernel and mesocarp was performed in appropriate equipments. The starch content in the mesocarp fractions of babassu coconuts dried at 75 and at $90{ }^{\circ} \mathrm{C}$ were 54 and $56 \%$, respectively and lipids represented $65 \%$ of the kernel. Oil and press cake were obtained through hydraulic and continuous press, biodiesel was produced and the quality of products was compared. The total of saturated fatty acid in babassu oil was between 78 and $82 \%$, and the total of unsaturated fatty acids that promote good oxidative stability in the oil was in the range of 17 to $20 \%$. Oil obtained by cold pressing extraction and its biodiesel had better results in terms of quality. The quality of oils is within the Codex standard and biodiesel from oil extracted by cold pressing had higher oxidative stability.

Keywords: biofuel, quality, integral use
\end{abstract}

Received August 14, 2014

Accepted February 05, 2015 from the biomass resources available in babassu in Brazil point to a possible source for the generation of biofuel (Teixeira and Carvalho, 2007).

The process most commonly used for transforming triacylglycerides into biodiesel is transesterification which involves the reaction of those with a lower molecular weight alcohol in the presence of a catalyst to produce fatty acid monoesters (Ferrari et al., 2005). To add value to products obtained through the technological processing of babassu coconuts, this study aimed to test the drying conditions at temperatures of 75 and $90{ }^{\circ} \mathrm{C}$, the separation of fractions rich in starch, fiber, kernels and mesocarp; and the characterization of the products obtained. Oil extraction was performed in two types of presses, hydraulic and continuous, biodiesel was produced by transesterification, and the quality of the products compared.

\section{Materials and Methods}

Fruit of the babassu (Orbignya sp.) used in this study was collected in the states of Goiás and São Paulo, Brazil during the harvest season of 2012. Among the equipment used was the use of abrasive peelers to remove the fibers and starch fractions of the babassu fruit; a babassu coconut cutter; hydraulic press and continuous press expeller.

\section{Sample preparation and press conditions}

Babassu coconuts were subjected to the drying process in an oven with forced air circulation at 75 and $90^{\circ} \mathrm{C}$ for $24 \mathrm{~h}$ to verify which would be the most suitable for obtaining better quality derivatives. Separation of the 
fractions was performed according to Soler et al. (2007), mesocarp flour was separated from the fibrous part of the epicarp by a 20-mesh sieve and the yield determined gravimetrically. The babassu kernels were subjected to a mechanical pressing process in a hydraulic press (cold pressing); and continuous pressing was performed using a stainless steel expeller with a capacity for pressing $40 \mathrm{~kg}$ of material per hour. Oil and press cake were obtained in both cases. The yield from the process was obtained by gravimetry. The oils obtained were filtered.

\section{Characterization}

The fractions obtained after processing babassu were characterized for proximate composition following the official AOCS method (2013), by determining the moisture, protein, lipid, and ashes which when subtracted from the total weight of the sample resulted in a difference considered carbohydrate. The exocarp was characterized for crude fiber according to Diemair (1963), acid detergent fiber (ADF) according to AOAC (2005), and neutral detergent fiber (NDF) according to Soest et al. (1991). The mesocarp was characterized as the starch content according to Diemair (1963), and was subjected to microscopic analysis for visualization of the structure of the starch granules. Oils obtained by hydraulic and continuous pressing were analyzed for free fatty acid, refractive index, peroxide value, unsaponifiable matter, saponification value, melting point iodine value and oxidative stability in Rancimat (Methron Brand Model 679) at $130{ }^{\circ} \mathrm{C}$ and $10 \mathrm{~L} \mathrm{~h}^{-1}$ of air following AOCS (2013) methodologies.

The biodiesel was characterized in relation to a number of technical specifications for Brazilian biodiesel (Resolution 13 of the National Petroleum, Natural Gas and Bio-fuels, ANP, dated March, 2013), using the following methods: ABNT NBR 7148 for specific gravity at $20^{\circ} \mathrm{C}\left(\mathrm{kg} \mathrm{m}^{-3}\right)$, ASTM D 6304 for water content $\left(\mathrm{mg} \mathrm{kg}^{-1}\right)$, ASTM D874 for the sulfated ash content (\%), ASTM D4294/5453 for the total sulfur content (\%), ASTM D664 for the acid number $\left(\mathrm{mg} \mathrm{KOH} \mathrm{g}^{-1}\right)$, visual aspect, EN 14538 for the calcium, magnesium, sodium and potassium contents, EN 14107 for the phosphorous content and EN 14111 for the iodine number. Oxidative stability was evaluated in Rancimat (Methron Brand Model 679) at $110{ }^{\circ} \mathrm{C}$ with $10 \mathrm{~L} \mathrm{~h}^{-1}$ of air (ANP, 2014).

\section{Fatty acid composition}

After extraction, the oils were saponified and the fatty acids converted to methyl esters as described by Hartman and Lago (1973). The fatty acid methyl esters were analysed in a chromatograph equipped with a flame ionisation detector, a split/splitless injector and a capillary column of melted silica $(30 \mathrm{~m} \times 0.25 \mathrm{~mm}, 0.20$ $\mu \mathrm{m})$, containing polyethylene glycol as the stationary phase. The chromatographic conditions used included the following: FID detector, $260{ }^{\circ} \mathrm{C}$, nitrogen make-up

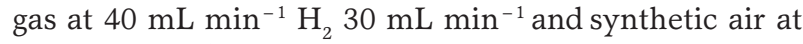
$300 \mathrm{~mL} \mathrm{~min}^{-1}$, injector temperature of $250{ }^{\circ} \mathrm{C}$, column temperature of $200{ }^{\circ} \mathrm{C}$ for $20 \mathrm{~min}$, programmed for 1 ${ }^{\circ} \mathrm{C}$ per minute up to $220{ }^{\circ} \mathrm{C}$, hydrogen gas with flow

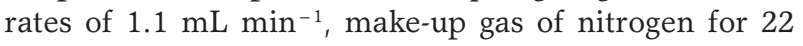
$\mathrm{mL} \mathrm{min}^{-1}$. The fatty acids were identified by comparing the retention times of the sample peaks with those of methyl ester standards of the fatty acids. The areas of the peaks were calculated and expressed as a percentage of the total area.

\section{Transesterification}

Biodiesel by transesterification was produced using anhydrous ethanol (purity $99 \%$ ) and sodium methylate solution $(30 \%)$ as the catalyst. Initially, $1 \mathrm{~kg}$ of crude oil was added to the $5 \mathrm{~L}$ reactor, which was heated to $45^{\circ} \mathrm{C}$. The mechanical stirrer was first set at $580 \mathrm{rpm}$ until the oil had reached the ideal temperature. After adding the catalytic solution ( $2 \%$ of sodium methylate) and $30 \%$ of anhydrous ethanol by vegetable oil weight, the rotation was reduced to $415 \mathrm{rpm}$ and maintained at this level until conversion into biodiesel occurred. For the final reaction stage, the rotation was again increased to $580 \mathrm{rpm}$. Adjustment of the rotation took into account the mixing intensity required for adequate blending of the chemical reagents with the oil as evaluated visually, favoring mass transfer during the transesterification reaction and avoiding excessive air incorporation during the process. The mixture was then left to decant for 6 $\mathrm{h}$ to allow for separation of the glycerol and ester-rich phases. Any excess ethanol in the ester-rich phase was evaporated off under reduced pressure at a temperature below $60{ }^{\circ} \mathrm{C}$. The sample obtained, containing no ethanol, was called the "unpurified biodiesel", and was subjected to the purification method consisting of washing the biodiesel with a $5 \%$ solution of hydrochloric acid (37 $\%)$, heated to $90^{\circ} \mathrm{C}$ (Ferrari et al., 2005).

\section{Statistics}

All analyses were performed in triplicate and the mean and standard deviation value reported.

\section{Results and Discussion}

Yieds of dried processed coconut babassu are listed in Table 1. Higher amount of kernels was observed on samples dryed at $75{ }^{\circ} \mathrm{C}$, however the variation depends on the quantity ofkernels presents in the samples (Figure 1). In this study, variation of two to eight kernels inside the fruits was observed. Soler et al. (2007) observed fruits of babassu with similar amount of epicarp, mesocarp and smaller amounts of kernels. The epicarp, mesocarp and endocarp of babassu are considered residue of babassu oil extraction and presented a significant energy potential. Lipids represented over 65 $\%$ of the kernel constitution (Table 2), similar to the level reported by Sidibé et al. (2010).

The epicarp fraction presented a high level of carbohydrates, mainly fiber compounds. The epicarp samples of the babassu coconut dried at 75 and $90{ }^{\circ} \mathrm{C}$ had 59 
and $61 \%$ of crude fiber; 65 and $62 \%$ ADF; 88 and $84 \%$ $\mathrm{NDF}$, respectively. Knowing the percentage of NDF and ADF of the material, it is possible to calculate the fraction of hemicellulose as the difference between these fractions (Soest, 1963). Therefore, the epicarp dried at 75 and $90{ }^{\circ} \mathrm{C}$ present $23 \%$ and $22 \%$ hemicellulose, respectively. Hemicellulose can be used to produce single-cell proteins, cellulolytic enzymes, mushrooms, resins and plastics, pharmaceuticals, furfuryl alcohol, mono-chloroacetic acid, herbicides, tetrahydrofufurylic alcohol and maleic anhydride (Reddy and Yang, 2005).

The starch content in the mesocarp fractions of babassu coconuts dried at 75 and at $90{ }^{\circ} \mathrm{C}$ were 54 and 56 $\%$ respectively, similar to that reported by Baruque Filho et al. (2000), which with apropriated processing can be used for food preparation. The aspect of babassu starch is similar to corn starch (Figure 2), as reported by Souza and Andrade (2000).

Table 1 - Yield of fractions of babassu coconuts dried at 75 and $90^{\circ} \mathrm{C}$.

\begin{tabular}{lcr}
\hline Fraction & $75^{\circ} \mathrm{C}$ & \multicolumn{1}{c}{$90^{\circ} \mathrm{C}$} \\
\hline Epicarp (\%) & $11.87 \pm 0.03^{*}$ & $13.77 \pm 0.01$ \\
Mesocarp (\%) & $11.67 \pm 0.12$ & $12.92 \pm 0.01$ \\
Endocarp (\%) & $63.77 \pm 0.88$ & $63.40 \pm 0.91$ \\
Kernel (\%) & $6.85 \pm 0.01$ & $3.61 \pm 1.03$ \\
\hline
\end{tabular}

"mean and standard deviation.

\section{Press oil yield}

The cold press had a better performance than the continuous press and lower losses in the process, 2 and $13 \%$ extraction of babassu kernel dried at $75{ }^{\circ} \mathrm{C}$ and $>$ 1 and $7 \%$ at $90{ }^{\circ} \mathrm{C}$ respectively (Table 3). The oil yield was 28 and $31 \%$ in the continuous press while in the hydraulic press it was 49 and $44 \%$. Mechanical methods are the oldest methods of oil extraction (Pighinelli and Gambetta, 2012), and the great advantage of these methods is that they do not use any kind of chemical product, and produce a crude oil of high quality, ready for consumption, in certain cases. Other important advantages are the low cost of acquisition of equipment, low power consumption for operations and manpower that does not need to be skilled.

Despite the environmental advantages, the economics are unfavorable, since although the facilities have lower costs than those in the chemical process, the oil yield is low, and the oil content high in the cake. The process most commonly used commercially is solvent extraction, as this process has the advantage of high oil yield (over $98 \%$ ) and total domination of the technological process. However, it presents the disadvantage of using chemical solvents. After oil extraction, the remaining solvent should have a proper disposal process to prevent environmental damage and avoid additional costs in the process, as well as having a higher investment cost (i.e. costly equipment). Another serious problem is the removal of

Table 2 - Proximate composition of the fractions obtained from babassu coconuts dried at 75 and $90{ }^{\circ} \mathrm{C}$.

\begin{tabular}{|c|c|c|c|c|c|c|}
\hline \multirow{2}{*}{ Constituent } & \multicolumn{2}{|c|}{ Epicarp } & \multicolumn{2}{|c|}{ Mesocarp } & \multicolumn{2}{|c|}{ Kernel } \\
\hline & $75^{\circ} \mathrm{C}$ & $90^{\circ} \mathrm{C}$ & $75^{\circ} \mathrm{C}$ & $90^{\circ} \mathrm{C}$ & $75^{\circ} \mathrm{C}$ & $90^{\circ} \mathrm{C}$ \\
\hline Moisture (\%) & $4.8 \pm 0.0^{* *}$ & $4.8 \pm 0.1$ & $5.2 \pm 0.2$ & $4.9 \pm 0.0$ & $3.9 \pm 0.0$ & $3.2 \pm 0.0$ \\
\hline Ashes (\%) & $1.4 \pm 0.1$ & $1.5 \pm 0.0$ & $4.6 \pm 0.1$ & $3.6 \pm 0.1$ & $1.7 \pm 0.1$ & $1.52 \pm 0.1$ \\
\hline Lipid (\%) & $0.3 \pm 0.0$ & $0.2 \pm 0.0$ & $0.7 \pm 0.1$ & $0.5 \pm 0.0$ & $67.3 \pm 0.2$ & $65.1 \pm 0.1$ \\
\hline Protein (\%) & $1.2 \pm 0.2$ & $2.2 \pm 0.1$ & $2.4 \pm 0.1$ & $2.5 \pm 0.1$ & $9.4 \pm 0.1$ & $8.9 \pm 0.1$ \\
\hline Carbohydrate $^{*}(\%)$ & $92.2 \pm 0.3$ & $91.2 \pm 0.2$ & $87.1 \pm 0.3$ & $88.3 \pm 0.2$ & $17.6 \pm 0.1$ & $21.2 \pm 0.2$ \\
\hline
\end{tabular}

*calculated by difference; * ${ }^{*}$ mean and standard deviation.

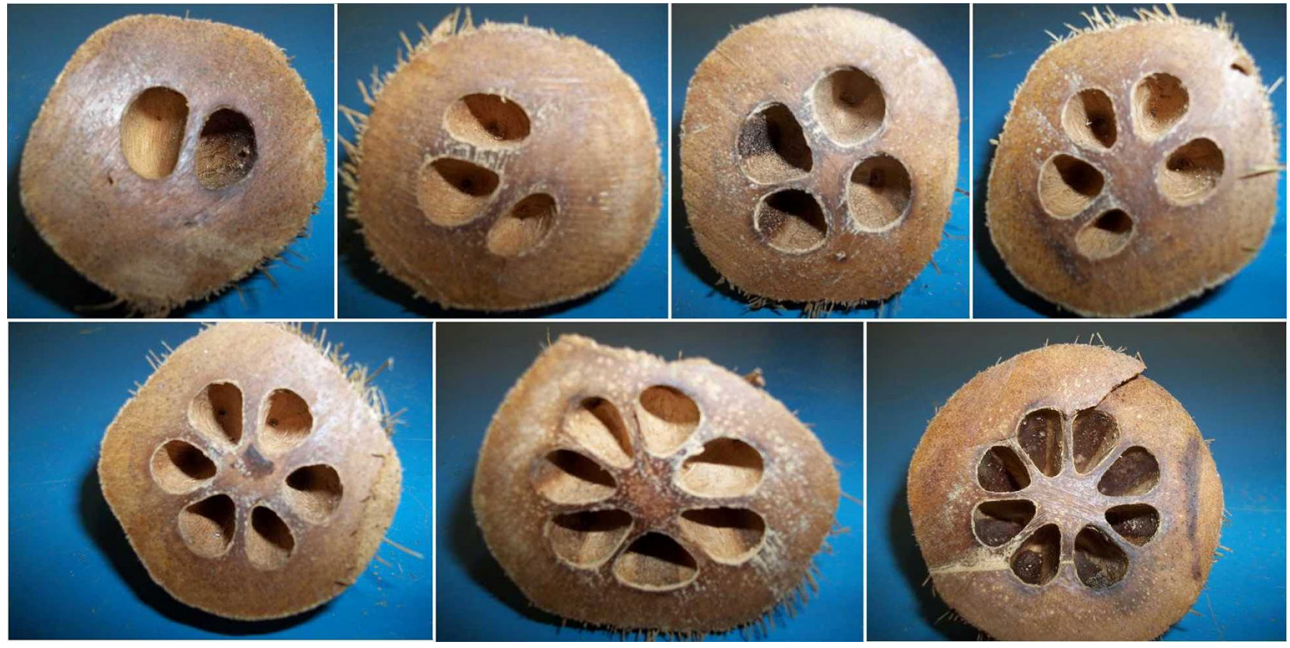

Figure 1 - Variation in the amount of kernels in babassu coconuts. 


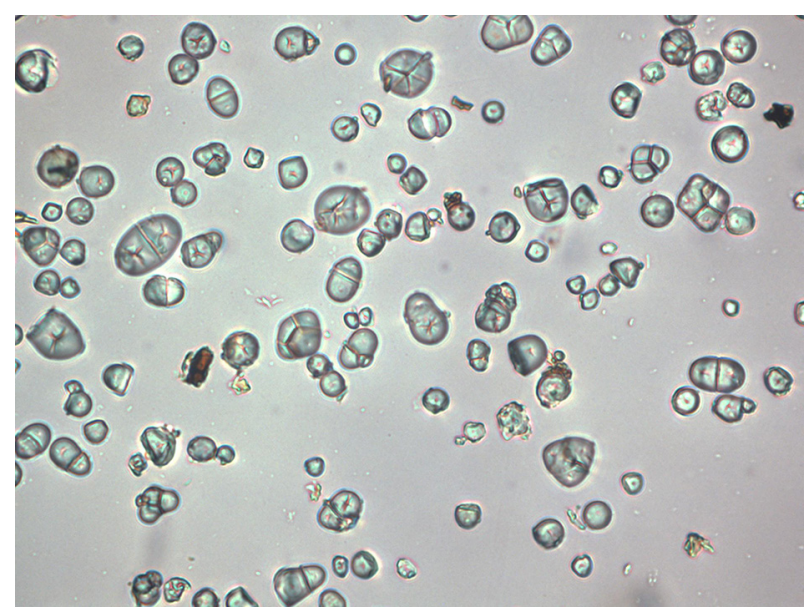

Figure 2 - Structures of starch granules of babassu (40x magnification).

Table 3 - Average yield of cold and continuous pressing extraction of kernels from babassu dried at temperatures of 75 and $90{ }^{\circ} \mathrm{C}$.

\begin{tabular}{lcrrrr}
\hline \multirow{2}{*}{ Yield } & \multicolumn{2}{c}{ Cold press } & & \multicolumn{2}{c}{ Continuous press } \\
\cline { 2 - 3 } \cline { 5 - 6 } & \multicolumn{1}{c}{$75^{\circ} \mathrm{C}$} & \multicolumn{1}{c}{$90^{\circ} \mathrm{C}$} & & $75^{\circ} \mathrm{C}$ & \multicolumn{1}{c}{$90^{\circ} \mathrm{C}$} \\
\hline Press cake (\%) & $49.0 \pm 0.3^{*}$ & $55.2 \pm 0.8$ & & $59.0 \pm 0.4$ & $61.1 \pm 0.5$ \\
Oil (\%) & $49.3 \pm 0.2$ & $44.5 \pm 0.5$ & & $28.0 \pm 0.2$ & $31.8 \pm 0.3$ \\
Losses (\%) & $1.7 \pm 0.5$ & $0.3 \pm 0.1$ & & $13.0 \pm 0.1$ & $7.1 \pm 0.1$ \\
\hline
\end{tabular}

*mean and standard deviation.

the solvent from vegetable oil, so as to ensure adequate levels that are not harmful to human health. This process is not recommended for oilseeds with high oil content in their composition. The energy consumed in operating a plant for solvent extraction is high, and skilled labor is required to service this complex operation.

Mechanical oil extraction produces a very important by-product named press cake. Some oil seed press cakes have high nutritional value and can be used as human food. Some are not suitable as food, but serve to complement the diet of chickens, pigs and cattle. It is important to emphasize the need for proper storage of seeds and cakes as they must be protected against the action of moisture, rodents and insects. High moisture content will generate mold, which can alter the taste of cakes and subsequent rejection by the animals. Another problem is the development of mycotoxins such as aflatoxin, which, in high concentrations, can be poisonous to both humans and animals (Bachmann, 2004).

Babassu press cake had a high level of carbohydrates and proteins, with differences in lipid levels between continuous pressing samples (Table 4). The cold pressing results in a press cake with higher residual oil.

\section{Fatty acid composition}

Oils were are rich in lauric acid (C12:0) (Table 5), that are in accordance with standards established by the FAO (2014) and this result is in agreement with that ob-
Table 4 - Proximate composition of the press cakes obtained from babassu coconuts dried at 75 and $90{ }^{\circ} \mathrm{C}$.

\begin{tabular}{|c|c|c|c|c|}
\hline \multirow{3}{*}{ Constituent } & \multicolumn{4}{|c|}{ Press cake } \\
\hline & \multicolumn{2}{|c|}{ Cold press } & \multicolumn{2}{|c|}{ Continuous press } \\
\hline & $75^{\circ} \mathrm{C}$ & $90^{\circ} \mathrm{C}$ & $75^{\circ} \mathrm{C}$ & $90{ }^{\circ} \mathrm{C}$ \\
\hline Moisture (\%) & $7.3 \pm 0.0^{* *}$ & $6.5 \pm 0.0$ & $3.7 \pm 0.0$ & $2.5 \pm 0.0$ \\
\hline Ashes (\%) & $3.5 \pm 0.1$ & $3.6 \pm 0.1$ & $4.32 \pm 0.0$ & $3.1 \pm 0.1$ \\
\hline Lipid (\%) & $28.8 \pm 0.1$ & $34.3 \pm 0.2$ & $11.1 \pm 0.1$ & $21.0 \pm 0.2$ \\
\hline Protein (\%) & $18.8 \pm 0.0$ & $21.8 \pm 0.1$ & $23.5 \pm 0.1$ & $25.3 \pm 0.1$ \\
\hline Carbohydrate $^{*}(\%)$ & $41.5 \pm 0.1$ & $33.9 \pm 0.1$ & $57.4 \pm 0.1$ & $48.1 \pm 0.1$ \\
\hline
\end{tabular}

tained by Moser (2009). Lauric oils and their derivatives have many applications in both the food and chemical industries. The richest common sources of lauric acid are coconut oil, palm kernel oil, and babassu (Sikorski, 2002).

The total of saturated fatty acid in babassu oil was between 78 to $82 \%$, and the total of unsaturated fatty acids was in the range of 17 to $20 \%$ that promote good oxidative stability in the oil. Babassu oil is mainly saturated, which makes it an excellent alternative for biodiesel production (Lima et al., 2007). In fact, in Brazil, there is a range of oilseed crops that can be used in biodiesel production; currently almost all manufacturing processes use soybean oil as the main raw material. However, some oilseeds, especially soybean oil, run directly into the food industry market, though the area required must be extensive if good production is to be achieved. Because of this inedible crops, such as babassu oil which present annual productivity and a good yield per hectare, have become an excellent alternative.

\section{Oil physicochemical characteristics}

All oils exhibited the same refractive index and melting point (Table 6), and the oils extracted from the seeds of the babassu dried at $75^{\circ} \mathrm{C}$ showed the same iodine value; and the same occurred with the oil extracted from the seeds of the babassu dried at $90{ }^{\circ} \mathrm{C}$. The oil of babassu coconut dried at $75^{\circ} \mathrm{C}$ obtained by cold pressing showed a higher amount of unsaponifiable matter and lower peroxide value and free fatty acid content. Comparing the data obtained with the Codex standard (2014), all the oils obtained from babassu coconuts are within the limits of the quality desirable for consumption without refining. The free fatty acids and peroxide value of the oils indicate that the preparation of raw material and the press processing of babassu kernel produced crude oil of good quality.

\section{Biodiesel characterization}

The biodiesel and glicerol phase mass yields were 973 and $130 \mathrm{~g}$, respectively. In Brazil, biodiesel is regulated by the ANP - the National Agency of Petroleum, Natural Gas and Biofuels. The biodiesel samples from babassu kernel oil presented a clean and limpid aspect. The characteristics of biodiesel babassu oils as well as the ANP (2014) specification can be seen in Table 7. Both 
Table 5 - Fatty acid composition (\%) of oils obtained by cold and continues pressing of kernels of babassu dried at 75 and $90{ }^{\circ} \mathrm{C}$.

\begin{tabular}{|c|c|c|c|c|c|}
\hline \multirow{2}{*}{ Fatty acid (\%) } & \multicolumn{2}{|c|}{ Cold press } & \multicolumn{2}{|c|}{ Continuous press } & \multirow{2}{*}{ Codex Standard } \\
\hline & $75^{\circ} \mathrm{C}$ & $90^{\circ} \mathrm{C}$ & $75^{\circ} \mathrm{C}$ & $90^{\circ} \mathrm{C}$ & \\
\hline C 6:0 Caproic & $0.27 \pm 0.00 * *$ & $0.29 \pm 0.00$ & $0.22 \pm 0.00$ & $0.26 \pm 0.00$ & 0.05 \\
\hline C 8:0 Capryllic & $4.77 \pm 0.01$ & $5.24 \pm 0.00$ & $4.25 \pm 0.00$ & $5.01 \pm 0.00$ & $2.6-7.3$ \\
\hline C 10:0 Capric & $5.21 \pm 0.01$ & $5.86 \pm 0.00$ & $4.78 \pm 0.00$ & $5.92 \pm 0.00$ & $1.2-7.6$ \\
\hline C 12:0 Lauric & $42.79 \pm 0.02$ & $44.49 \pm 0.03$ & $42.6 \pm 0.01$ & $45.21 \pm 0.02$ & $40.0-55.0$ \\
\hline C 14:0 Myristic & $14.11 \pm 0.01$ & $14.3 \pm 0.00$ & $14.54 \pm 0.02$ & $14.16 \pm 0.01$ & $11.0-27.0$ \\
\hline C 16:0 Palmitic & $8.85 \pm 0.03$ & $8.69 \pm 0.00$ & $9.03 \pm 0.00$ & $8.46 \pm 0.00$ & $5.2-11.0$ \\
\hline C 18:0 Stearic & $3.57 \pm 0.02$ & $3.44 \pm 0.01$ & $3.40 \pm 0.00$ & $3.53 \pm 0.00$ & $1.8-7.4$ \\
\hline C 18:1 Oleic & $17.48 \pm 0.01$ & $15.37 \pm 0.00$ & $18.33 \pm 0.00$ & $15.00 \pm 0.00$ & $9.0-20.0$ \\
\hline C 18:2 Linoleic & $2.88 \pm 0.00$ & $2.32 \pm 0.00$ & $2.79 \pm 0.00$ & $2.45 \pm 0.00$ & $1.4-6.6$ \\
\hline C 20:0 Araquidic & $0.07 \pm 0.00$ & $\mathrm{n} . \mathrm{d}^{*}$ & $0.06 \pm 0.00$ & n.d & 0.05 \\
\hline $\begin{array}{l}\text { S Saturated } \\
\end{array}$ & $79.64 \pm 0.03$ & $82.31 \pm 0.03$ & $78.88 \pm 0.02$ & $82.55 \pm 0.02$ & $61.90-115.4$ \\
\hline$\Sigma$ Monounsaturated & $17.48 \pm 0.01$ & $15.37 \pm 0.00$ & $18.33 \pm 0.00$ & $15.00 \pm 0.00$ & $9.0-20.0$ \\
\hline$\Sigma$ Polyunsaturated & $2.88 \pm 0.00$ & $2.32 \pm 0.00$ & $2.79 \pm 0.00$ & $2.45 \pm 0.00$ & $1.4-6.6$ \\
\hline
\end{tabular}

${ }^{*}$ nd $=$ not detected; ${ }^{*}$ *mean and standard deviation.

Table 6 - Characteristics of oils from babassu dried at 75 and $90{ }^{\circ} \mathrm{C}$ and Codex standard.

\begin{tabular}{|c|c|c|c|c|c|}
\hline \multirow{2}{*}{ Characteristic } & \multicolumn{2}{|c|}{ Cold press } & \multicolumn{2}{|c|}{ Continuous press } & \multirow{2}{*}{ Codex Standard } \\
\hline & $75^{\circ} \mathrm{C}$ & $90^{\circ} \mathrm{C}$ & $75^{\circ} \mathrm{C}$ & $90^{\circ} \mathrm{C}$ & \\
\hline Free fatty acid (\%) & $0.81 \pm 0.01^{* *}$ & $1.29 \pm 0.00$ & $0.87 \pm 0.01$ & $1.24 \pm 0.00$ & Max. 4.0 \\
\hline Peroxide value (meq $\mathrm{O}_{2} \mathrm{~kg}^{-1}$ ) & $0.66 \pm 0.00$ & $1.16 \pm 0.01$ & $0.86 \pm 0.01$ & $0.95 \pm 0.01$ & Max. 15 \\
\hline lodine value $\left(\mathrm{g} \mathrm{I}_{2} 100 \mathrm{~g}^{-1}\right)$ & $20 \pm 0.00$ & $17.2 \pm 0.01$ & $20.6 \pm 0.00$ & $17.1 \pm 0.01$ & $10-18$ \\
\hline Saponification value (mg KOH g-1) & $236.69 \pm 0.01$ & $239.62 \pm 0.01$ & $235.50 \pm 0.01$ & $239.74 \pm 0.01$ & $245-256$ \\
\hline Unsaponifiable matter (\%) & $0.80 \pm 0.01$ & $0.24 \pm 0.00$ & $0.24 \pm 0.00$ & $0.28 \pm 0.01$ & $\leq 12$ \\
\hline Refractive index $40^{\circ} \mathrm{C}$ & $1.451 \pm 0.00$ & $1.451 \pm 0.00$ & $1.451 \pm 0.00$ & $1.451 \pm 0.00$ & $1.448-1.451$ \\
\hline Oxidative Stability (h) & $6.77 \pm 0.01$ & $2.03 \pm 0.01$ & $14.00 \pm 0.01$ & $17.10 \pm 0.01$ & $n i^{*}$ \\
\hline Melting point $\left({ }^{\circ} \mathrm{C}\right)$ & $23.63 \pm 0.01$ & $23.10 \pm 0.02$ & $23.85 \pm 0.03$ & $22.90 \pm 0.01$ & ni \\
\hline
\end{tabular}

${ }^{*}$ ni = not informed; ** mean and standard deviation.

Table 7 - Biodiesel parameters obtained from babassu oil by cold press, continuous pressing and ANP specification.

\begin{tabular}{|c|c|c|c|}
\hline Parameter & $\begin{array}{l}\text { Biodiesel } \\
\text { cold press }\end{array}$ & $\begin{array}{c}\text { Biodiesel } \\
\text { continuous press }\end{array}$ & $\begin{array}{c}\text { ANP } \\
\text { Specification }\end{array}$ \\
\hline Aspect & Limpid & Limpid & Limpid \\
\hline Ash content (\%) & $\mathrm{nd}^{*}$ & nd & $<0.02$ \\
\hline Sulphur (mg kg-1) & $12.6 \pm 1.0^{* *}$ & $13.6 \pm 1.4$ & $<10$ \\
\hline Sodium (mg kg-1) & $\mathrm{nd}<2.6$ & $\mathrm{nd}<2.6$ & $<5$ \\
\hline Potassium (mg kg-1) & $\mathrm{nd}<0.5$ & $\mathrm{nd}<0.5$ & $<5$ \\
\hline Calcium (mg kg-1) & $\mathrm{nd}<0.5$ & $\mathrm{nd}<0.5$ & $<5$ \\
\hline Magnesium (mg kg-1) & $\mathrm{nd}<0.5$ & $\mathrm{nd}<0.5$ & $<5$ \\
\hline Phosphorus (mg kg-1) & $\mathrm{nd}<2.6$ & $\mathrm{nd}<2.6$ & 10 \\
\hline Oxidative Stability (h) & $11.4 \pm 0.1$ & $5.08 \pm 0.0$ & $>6$ \\
\hline Acid value (mg KOH g-1) & $0.16 \pm 0.2$ & $0.12 \pm 0.0$ & $<0.50$ \\
\hline lodine value (g 100 g) & $18.93 \pm 0.2$ & $19.12 \pm 0.1$ & Report \\
\hline Water content (ppm) & $210 \pm 2.3$ & $260 \pm 0.5$ & $<350$ \\
\hline
\end{tabular}

${ }^{*}$ nd $=$ not detected; ** mean and standard deviation.

samples exceeded the limits with respect to the amount of sulfur, probably inherent in the raw material. The biodiesel sample extracted from the continuous press lacks the oxidative stability necessary for the addition of antioxidant to attend that specified by the current legislation.
The water content of the samples was below the limit stipulated by Brazilian legislation. The presence of water is not desirable, since it promotes hydrolysis of the biodiesel resulting in the production of free fatty acids, and also because it allows for microbial proliferation as per Lôbo (2009). The other parameters evaluated were according to ANP specifications for biodiesel.

\section{Conclusions}

The babassu coconuts dried at $75{ }^{\circ} \mathrm{C}$ for $24 \mathrm{~h}$ proved to be a suitable preparation process for obtaining oil of high quality. The cold pressing resulted in oil with better quality, and the lowest level of free fatty acid and peroxide. Press cake had a high level of carbohydrates, and press cake with higher residual oil was obtained by cold pressing. The mesocarp had high levels of starch, similar to corn granules, which can be availed for food. The biodiesel obtained from the oil extracted by cold press showed higher oxidative stability.

\section{Acknowledgments}

To the Brazilian National Council for Scientific and Technological Development (CNPq) for their support. 


\section{References}

Agência Nacional do Petróleo [ANP]. 2014. Resolution 13. Available at: http://www.anp.gov.br. [Accessed Apr 14, 2014] (in Portuguese).

Association of Official Analytical Chemists - International [AOAC]. 2005. Official Methods of Analysis. 18ed. AOAC, Gaithersburg, MD, USA.

American Oil Chemists' Society [AOCS]. 2013. Official Methods and Recommended Practices of the AOCS. Champaign, IL, USA.

Bachmann, J. 2004. Oil seed processing for small scale producers. Available at: http://www.attra.ncat.org/attra-pub/PDF/oilseed. pdf. [Acessed July 1, 2011]

Baruque Filho, E.A.; Baruque, M.G.; SantAnna Jr, G.L. 2000. Babassu coconut starch liquefaction: an industrial scale approach to improve conversion yield. Bioresourse Technology 75: 49-55.

Diemair, W. 1963. Laboratory Guide for Food Chemists = Laboratoriumsbuch fur Lebensmittelchemiker. Theodor Steinkopff, Dresden, Germany (in German).

Ferrari, R.A.; Oliveira, V.S.; Scabio, A. 2005. Biodiesel from soybean: characterization and consumption in an energy generator. Química Nova 28: 19-23 (in Portuguese, with abstract in English).

Ferrari, R.A.; Oliveira, V.S.; Scabio, A. 2005. Oxidative stability of biodiesel from soybean oil fatty acid ethyl esters. Scientia Agricola 62: 291-295.

Food and Agriculture Organization [FAO]. 2014. Codex standard for named vegetable oils. Available at: http://www. codexalimentarius.org/standards/list-of-standards/. [Accessed Apr 14, 2014]

Instituto Brasileiro de Geografia e Estatística [IBGE]. 2010. Production of vegetable extraction and silviculture = Produção da extração vegetal e da silvicultura. Available at: :http://www.sidra.ibge.gov.br/bda/extveg/default.asp?t = 2\&z $=t \& o=18 \& u 1=1 \& u 2=1 \& u 3=1$. [Accessed May 16, 2013] (in Portuguese).

Hartman, L.; Lago, R.C.A. 1973. Rapid preparation of fatty acid methyl esters from lipids. Laboratory Practice 22: 475-494.

Lima, J.R.; Silva, R.B.; Silva, C.C.M.; Santos, L.S.S.; Santos Jr, J.R.; Moura, E.M.; Moura, C.V.R. 2007. Biodiesel from babassu (Orbignya sp.) synthesized via ethanolic route. Química Nova 30: 600-603 (in Portuguese, with abstract in English).
Lôbo, I.P.; Ferreira, S.L.C.; Cruz, R.S. 2009. Biodiesel: quality parameters and analytical methods. = Biodiesel: parâmetros de qualidade e métodos analíticos. Química Nova 32: 15961608 (in Portuguese).

Moser, B.R. 2009. Comparative oxidative stability of fatty acid alkyl esters by accelerated methods. Journal of the American Oil Chemists' Society 86: 699-706.

Pighinelli, A.L.M.T.; Gambetta. R. 2012. Oil presses. p. 33-52. In: Uduak, G.A., ed. Oilseeds. InTech, Rijeka, Croatia.

Protásio, T.P.; Trugilho, P.F.; César, A.A.S.; Napoli, A.; Melo, I.C.N.A.; Silva, M.G. 2014. Babassu nut residues: potential for bioenergy use in the North and Northeast of Brazil. SpringerPlus 3: 1-14.

Reddy, N.; Yang, Y. 2005. Biofibers from agricultural byproducts for industrial applications. Trends in Biotechnology 23: 22-27.

Sidibé, S.S.; Blin, J.; Vaitilingom, G.; Azoumah, Y. 2010. Use of crude filtered vegetable oil as a fuel in diesel engines state of the art: literature review. Renewable and Sustainable Energy Reviews 14: 2748-2759.

Sikorski, E. 2002. Chemical and functional properties of food components. p. 367. In: Sikorski, E., ed. 2.ed. CRC Press, Boca Raton, FL, USA.

Silva, F.C.; Cavalcante, K.S.B.; Louzeiro, H.C.; Moura, K.R.; Maciel A.P.; Soledade, L.E.; Souza, A.G. 2010. Production of biodiesel from babassu oil using methanol-ethanol blends. Eclética Química 35: 47-54.

Soest, P.J. 1963. Use of detergents in the analysis of fibrous foods. II. A rapid method for the determination of fibre and lignin. Journal of the Association of the Official Analytical Chemists 46: 829-835.

Soest, P.J.; Robertson, J.B.; Lewis, B.A. 1991. Methods for dietary fiber, neutral detergent fiber, and nonstarch polysaccharides in relation to animal nutrition. Journal Dairy Science74: 3583.

Soler, M.P.; Muto, E.F.; Vitali, A.A. 2007. Babassu nut breaking technique (Orbignya speciosa). Ciência e Tecnologia de Alimentos 27: 717-722 (in Portuguese, with abstract in English).

Souza, R.C.R.; Andrade, C.T. 2000. Investigation of corn starch gelatinization and extrusion processes. Polímeros: Ciência e Tecnologia 10: 24-30 (in Portuguese, with abstract in English).

Teixeira, M.A. 2008. Babassu: a new approach for an ancient Brazilian biomass. Biomass Bioenergy 32: 857-864.

Teixeira, M.A.; Carvalho, M.G. 2007. Regulatory mechanism for biomass renewable energy in Brazil: a case study of the Brazilian Babassu oil extraction industry. Energy 32: 999-1005. 